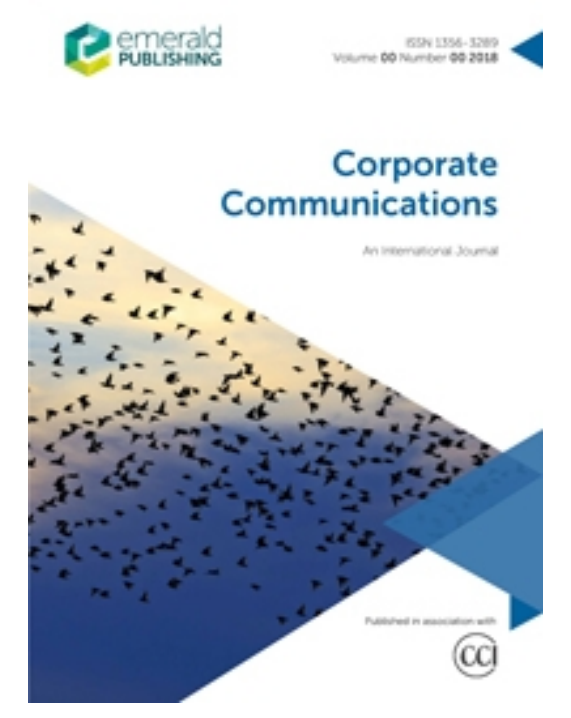

\title{
Corporate brand management in a charity context:The internal communications challenge
}

\begin{tabular}{|r|l|}
\hline Journal: & Corporate Communications: an International Journal \\
\hline Manuscript ID & CCIJ-05-2020-0083.R1 \\
\hline Manuscript Type: & Original Article \\
\hline Keywords: & Corporate branding, Internal communications, Non-profit organisations \\
\hline
\end{tabular}

\section{SCHOLARONE ${ }^{\text {M }}$ \\ Manuscripts}




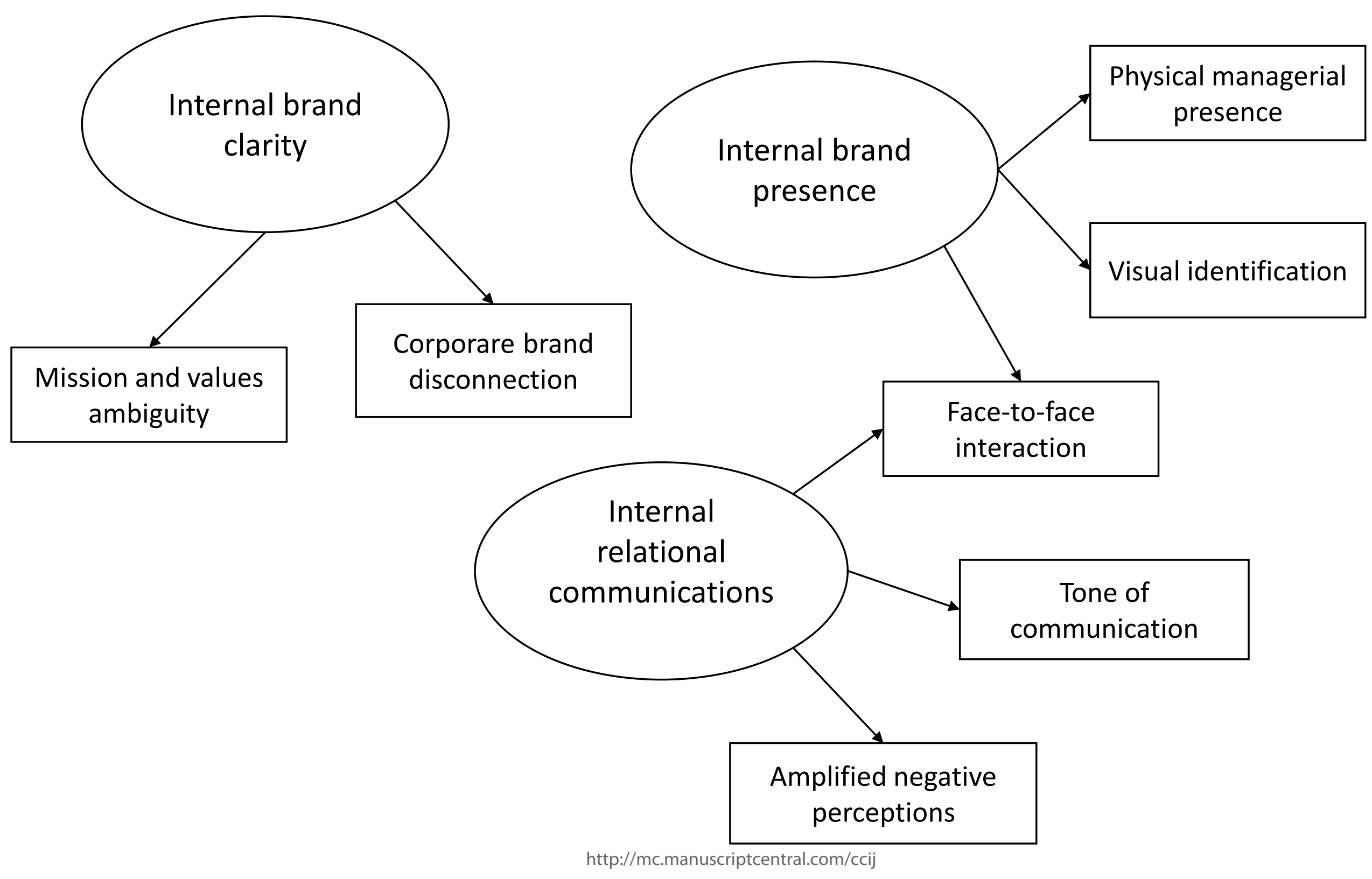




\section{Corporate brand management in a charity context: The internal communications challenge}

\section{Introduction}

An increasing number of charities have been involved in branding initiatives during the past decades (Stride, 2006) and many have realised the importance of branding as a means to "communicating value and meaning" (Hankinson 2001a, p. 231). Several high-profile charities in the UK embarked on branding strategies in the 1990s, resulting in their brand image improving within the country (Bennett and Gabriel, 2003), in addition to attracting more donor funding (Hankinson, 2001b). CharityComms, an organisation that networks charity communications professionals in the UK, has been actively encouraging the development of charity branding over the past decades by providing best practice guides and organising frequent workshops on the subject. Several high-profile charities in UK have also created specific brand management roles within their organizational hierarchy (e.g. Director of Brand, Head of Brand, etc.) indicating a more strategic consideration to corporate brand management in that sector.

Branding in the charity sector is not a new phenomenon. Griffiths (2005) even suggested that the for-profit brands have been borrowing several concepts from the charity context (e.g., vision, mission, and values) and have integrated these to the development of commercial brands. Hankinson (2004) shared a similar view arguing that the idea of organisational or brand mission stemmed from the non-profit sector: "the idea of mission, so widely used now in profit-making organisations, comes from the not-for-profit sector and especially from organisations with an overtly Christian origin and purpose" (p. 92). Olins (2003) also pointed out that many charities have been involved in brand creation for centuries, well-before commercial enterprises, citing an example of the Red Cross. However, while certain aspects of branding may have its roots in the charity sector, the active management of the charity as a brand is relatively new (Hankinson, 2004).

The main aim of this study was to investigate the challenges and issues of managing a corporate brand internally within a charity that has been operating at a national level in the UK for several decades with numerous branches spread across the country. While previous studies have investigated charity brand management 
within similar settings (e.g. Hankinson, 2004; Chapleo 2015; Lui et al., 2015, Stride and Lee, 2007), most of these studies have favoured insights gathered from the perspectives of senior managers only. One key stakeholder group - volunteers who assist in representing the brand at grassroots level - have seldom had their voices heard in studies exploring issues or tensions around corporate brand management within a charity context. There have also been various studies in the charity branding literature that have proposed theoretical frameworks supposedly appropriate for the charity context, but there have been fewer studies investigating their practical applicability. Therefore, the following research questions guided this investigation: (1) How volunteers at grassroots level experienced the brand internally through the actions of senior management? (2) What were the practical issues and challenges faced in managing a charity brand internally from the perspectives of both senior managers and volunteers?

This paper starts with a literature review of the corporate brand concept before moving to how the notion of corporate branding has been applied and experienced with a charity context. The host organisation in which this study took place is then presented to provide a context for this study. A brief methodology is then presented and, subsequently, findings from in-depth interviews conducted with both senior management and purposively selected volunteers are presented. Our analysis revealed three main issues centered around internal brand clarity, internal communications and internal brand presence. The paper concludes with a number theoretical and managerial implications as well as areas for future research.

\section{Literature Review}

The corporate brand concept

The notion of 'company as brand' has gained increasing attention from academics and practitioners in past decades (Knox and Bickerton, 2000; Schultz and de Chernatony, 2002), with the term 'corporate brand' emerging as an umbrella term to refer to this notion. The English word 'corporate' has its roots in the Latin word corpus, meaning body (Kapferer, 2002). The concept first originated from the idea of 'company brand' where scholars like King (1991) were advancing the idea of thinking of the company as a brand. Subsequently, the term 'corporate brand' started to appear 
in the literature (Balmer, 1995; Macrae, 1999; Kapferer, 2002) and soon the term 'company brand' was replaced to give way to the notion of a corporate brand instead. According to Balmer and Grey (2003), the main reason for this shift in terminology was due to the fact that the word 'company' was restricted to one specific legal business structure, while the word 'corporate' has a broader circumference and could include the study of other organisational structures; that is, not only corporations and their subsidiaries, but also charities, governmental agencies, universities, religious bodies, and international non-profit agencies (Balmer, 2006). Hence the notion of a corporate brand is now used more generally to refer to an organisation brand (Balmer, 2006; Roper and Davies, 2007).

However, the notion of 'corporate branding' has been suffering from confusion since its introduction, as noted by some leading scholars in the field (King, 1991; de Chernatony, 2002; Balmer, 2006). In many cases, the term 'corporate brand' has been used (and maybe is still being used) as a synonymous term for corporate identity (King, 1991; Balmer, 1998; Balmer, 2001; Kitchen et al., 2013). Moreover, the notion of corporate identity itself has suffered from diverging interpretations since its inception, due to the divergences in terminologies from diverse disciplines (Van Riel and Balmer, 1997). These diverging terminologies and interpretations have created what Balmer (2001) metaphorically described as a fog in the field of 'business identity' (p. 249) - a term he uses to encompass the related notions of corporate identity, organisational identity and visual identity. He pointed out that the term 'business identity' refers not only to commercial organisations, but also to non-profit organisations (Balmer, 2001), giving an indication that such studies could be relevant to non-profit organisations as well. Hatch and Schultz (2001) suggested that the nature of a corporate or organisational brand is such that it is both "complicated and nuanced" (p. 130) hence the many divergences in interpretations in the academic literature. De Chernatony (2002) argued that it was not necessary to have a separate definition for a 'corporate brand' and suggested a definition of 'brand' that could apply to any context. De Chernatony (2002) proposed the 'brand triangle' as a framework whereby the corporation would first identify its functional values, then its emotional values, and then combine both to propose a brand promise that would then be managed through external communication. De Chernatony (2002, p.118) suggested that this model 
could also be applied to non-profit organisations as well illustrating his point through the example of UNICEF:

The brand triangle is suitable for brands in different contexts. For example, in the non-for-profit sector, UNICEF link their corporate brand's functional values (e.g. respecting children's rights) with emotional values (e.g. integrity) to arrive at the brand's promise of working worldwide so that every child can reach their full potential...

While such a model could be criticised for its simplistic articulation of the corporate brand, it nevertheless demonstrated the relevance of brand at organisational level, even in non-profit environments. Balmer (2001) also postulated that, while organisations are born with identities, they are not necessarily born with a brand; this can only be developed through a conscious effort of distilling the salient aspects of the corporate identity. Leitch and Motion (2007) further elaborated on this principle stating that an organisation may choose to just have a corporate identity and be concerned with only creating product brands and not necessarily creating a corporate brand. Kitchen et al. (2013) also argued that organisations are created with corporate identities but do not necessarily feel the need to develop a corporate brand or wish to make a conscious effort to distil their identity into a corporate brand (Leitch and Motion 2007). However, Abratt and Kleyn (2010) argued that all organisations have corporate brands from the point of their inception "whether they make explicit choices to communicate it to all stakeholder groups or not" (p. 1053). Abratt and Kleyn (2010) supported this argument by explaining that the corporate brand is that of an expression of the corporate identity, and this expression necessarily happens whether it is triggered by management or not. Therefore, this literature review on the topic seems to suggest that the argument about whether organisations are born as brands or not, arises mainly due to the different perspectives of corporate identity and corporate branding as well as the lack of clarity in defining constructs (Gyrd-Jones, 2013).

\section{Corporate branding in a charity context}

Research on branding within the charity context started to appear within the academic literature during the 1990s with several papers published by brand practitioners. Roberts-Wray (1994) seemed to be the first to propose the application of commercial branding concepts to the charity sector, arguing that the most successful charities in the future "will be those charities who successfully market 
themselves as brands" (p.366). Saxton (1994) introduced the notion of organisational beliefs in the brand component, suggesting a three-stage belief-based brand development model centered on the core beliefs and values of the charity. This involved selecting the charity's beliefs, packaging these beliefs, and then communicating these beliefs to the targeted audience (Saxton, 1994). Tapp (1996) was interested in Saxton's (1994) idea and explored further the concept of brand in the charity context. Through his discussion with fundraising managers and his analysis of charity communication materials, Tapp (1996) observed that while charities were engaged in a functional form of branding, they were not devoting much effort in developing and differentiating their brand personalities. On the other hand, Grounds and Harkness (1998) argued that charities were inherently brands: "all charities are brands" ( $p .181$ ) though they suggested that charities needed to actively manage the three main components of their brand: vision, values, and visual identity. They also introduced for the first time in the charity brand literature, the concept of the 'internal brand' to refer to the importance of having internal stakeholders (staff and volunteers) buy into the brand building process so that the charity's brand "is reflected in everything it does" (p. 183). Ind and Bell (1999) also emphasised on the importance of generating a "core brand idea that employees could believe in and would be relevant to their day to day lives" (p.201).

In her study of brand orientation in charity organisations, Hankinson (2000) argued that a charity brand could be defined as a combination of the functional attributes related to the charity's cause with the symbolic values related to the charity's beliefs. In a later study, Hankinson (2004) investigated how brand was understood by charity managers and found that in the charity context, the brand was perceived as a "means of bringing people together behind a common purpose" (p. 87), allowing management to simplify and better communicate complex messages. Hankinson (2004) also observed that senior management teams understood the importance of "living by the values of the brand" (p. 88) and that the brand must be lived and owned by the whole organisation. Based on insights gathered from this study, Hankinson (2004) introduced the notion of the internal brand in a charity context, composed of four main components: functional (e.g. mission), symbolic (e.g. values and beliefs), behavioural (e.g. employee behaviour and managerial practice) and experiential (e.g. the general feel in the working environment). This study was a major development in 
the conceptualisation of the charity brand where components of an internal charity brand framework was inductively derived, based on a charity manager's perspective though these components could have been better articulated in terms of operational definitions. In a more comprehensive study among several global non-profit brands, Laidler-Kylander and Simonin (2009) observed the importance of internal branding in the development of brand equity among global nonprofit brands. They postulated that managing the brand from inside was critical in building the nonprofit's brand equity. The researchers also observed that internal branding was a common denominator throughout the whole organisation and concluded that "indeed, it is possible that for nonprofits, the role of the brand internally is as important, if not more important, than the external role" (p. 64).

Several scholars have also been advocating for greater emphasis on authenticity and values when considering charities as brands (Hankinson, 2004; Stride, 2006; Wylmer and Akbar, 2018). There also seemed to be a consensus among scholars regarding the need to acknowledge the specificities of the non-profit sector when conceptualising charities as brands (Pope et al., 2009). Laidler-Kylander and Stenzel (2013) even suggested new terminologies (e.g. brand integrity, brand democracy, brand affinity) that would be more appropriate to the nature of the sector. More recently, Garg et al., (2019) suggested that, for branding approaches to be effective in a charity context, charity executives understand "from which aspects of the organisation the stakeholders such as donors, volunteers, media, etc., derive the most value and then tailor their measures to satisfy their need" (p. 19).

\section{Corporate branding and internal stakeholders}

One main perspective of corporate branding in the academic literature is the acknowledgment of internal stakeholders (e.g. employees) as being of crucial importance to successful corporate brand management since they are the ones who physically deliver the brand promise (Punjaisri and Wilson, 2017). The role of employees and other internal stakeholders has also been emphasised in the cocreation corporate branding perspective which suggests that brands are constructed by corporations in interaction with their multiple stakeholders (Schultz et al. 2012). However, recent research has also postulated that such employee engagement in corporate branding might create a situation of brand cacophony especially in the context of large public organisations (Schmeltz and Kjeldsen, 2019). Suomi et al. 
(2019) also observed that in large and complex organisational settings (e.g. healthcare organisations) extra care should be taken in internal branding and internal communications due to the diverse and complex groups of employees.

Contextualising this study

A charity in the United Kingdom is legally considered as an organisation that has been set up for charitable purposes. Charitable purposes are those meant for public interest as per guidelines set by the relevant legislation (The Charity Act 2006 for England and Wales, The Charities and Trustee Investment Act 2005 for Scotland, and the Charities Act 2008 for Northern Ireland). Currently, according to the figures provided by the Charity Commission for England \& Wales, there are about 168,000 registered charities in England and Wales with a combined annual income of about 77 billion pounds (Charity Commission, 2020). The host organisation for this study was a healthcare charity in the UK operating at a national level and headquartered in London with the mission of supporting people affected by a particular medical condition.

At the time of the study, the charity was employing around 30 full-time paid staff and 28 part-time staff. The charity also had a network of branches across the UK managed by grassroots volunteers. Most of the charity's support services, such as the phone helplines, ordering/downloading of booklets, and use of online forum, are available for free to the public hence it is not a prerequisite to become a member to be able to use the services. This study started when the charity was in a process of restructuring due to financial pressures where senior management was working on possible future strategic orientations of the charity including rebranding and merger possibilities. This study was part of a doctoral research programme that started in 2010 and which was supported and co-funded by the charity and Bournemouth University. The author was an independent postgraduate researcher recruited to undertake independent research that would be beneficial to both the charity's senior management team and to the academic broader community. In this present paper, findings relating to the research objective of gaining more insights into how the corporate brand was experienced internally from the perspectives of both senior management and volunteers are presented and discussed. 


\section{Methodology}

An interpretive exploratory approach was adopted for this investigation to allow the researcher to capture the different social realities in existence, and to better understand the cultural and social context in which these realities are uncovered and interpreted (Foster and Bochner 2008). Emphasis was placed on giving voice to participants, considered as knowledge agents, that is, people who "know what they are trying to do and can explain their thoughts, intentions and actions" (Gioia et al., 2013 , p.17). The strategy of inquiry used by the researcher was that of an interpretive bricoleur (Denzin and Lincoln 2003) where research questions and data collection techniques were modified as research progressed on the field through an interactive process. In that respect, there was no rigid interview guide set, but participants were encouraged to share their thoughts and feelings and were encouraged to bring up themes that they felt were important. Much emphasis was laid on listening to the participant's voice, and interview questions changed as fieldwork progressed to "follow wherever the informants lead us in the investigation of our guiding research question" (Gioia et al., 2013, p.20). The findings presented in this paper are based on data collected from in-depth qualitative interviews carried out with 7 volunteers (including 5 branch chairs and 1 trustee) and 5 senior managers (CEO, head of fundraising, national director, regional director, and head of information and helplines) where the issues around internal branding emerged. The researcher also made visits to 5 branches to attend members' meetings and participated in 2 volunteer-targeted events. The objectives of participating in these events were to allow for the researcher to gain better insights into the social context and cultural milieu of the participants but to also recruit participants for the study. Recruiting participants proved to be more challenging than expected since in-depth qualitative interviews relied a lot on rapport building and participants' willingness to collaborate. Other limitations relating to adopting an such an exploratory interpretative approach included a limited sample frame, a less consistent data collection format, and a reliance on rapport building with participants. It also implied prolonged engagement on the field for "building trust with participants, learning the culture, and checking for misinformation that stems from distortions introduced by the researcher or informants" (Creswell 1998, p.201). 


\section{Findings}

Findings in this section are presented based on the themes and sub-themes that were generated from a coding of the data using the principles postulated by Braun and Clarke (2006). During the data analysis phase, the researcher avoided to be bound by a rigid conceptual framework or being influenced too much by the literature to avoid having conceptual blinkers hindering a wider-angle view on the phenomena. However, data analysis was not purely inductive because, upon consultation of the literature prior to data collection, some knowledge was acquired so the researcher was not "completely uninformed about prior work" (Gioia et al. 2013, p.21). The first step of the thematic analysis involved a repeated reading of the data set (interview transcripts) to identify patterns and meanings. This was followed by a coding of the data set which involved identifying "interesting aspects in the data items that may form the basis of repeated patterns across the data set" (Braun and Clarke, p. 89). At this stage, the researcher started to notice emerging concepts that seemed to relate to extant corporate branding and internal communications literature. Therefore, using a hybrid approach of inductive and deductive thematic data analysis, the analytical process resulted in the identification of several subthemes which were then grouped into three main underlying that were named as follows: (1) Internal brand clarity (2) Internal relational communications (3) Internal brand presence.

\section{Figure 1: Thematic map of main themes and sub-themes}

$$
\text { [Insert Figure } 1 \text { here] }
$$

\section{Internal brand clarity}

The notion of brand clarity within the organisation was found to be an important issue identified by both senior management and branch volunteers. There was a general feeling that the brand mission was not clear enough both for internal and external audiences. With regards to external audiences, the issue was that if people were not clear about what the charity is doing or if the charity itself is not clear in communicating what it is doing then that would have consequences on how and why people want to relate to with charity. There seemed to be an general agreement at senior management level that the mission of the charity brand was not clear and 
focussed enough and it is therefore not well translated within the organisation as explained by the head of fundraising who joined the organisation around nine months ago:

That was one think that was very difficult for me to pick up when I first came to the organisation. What does this organisation do? And we've looked at in terms of our branding and in terms of our marketing; trying to get that elevator pitch that you can, bang, tell somebody that this is what we do. And it is very difficult.

This perspective was reinforced by the regional director who had already spent several years within the charity. Based on her own experience on the field and dealing directly with branches at grassroots level, she also felt that the mission was not giving any sense of direction and purpose:

I think the mission is overly complicated. And I certainly think the vision statement that we have makes people not listen... That's incredibly lengthy and complicated to hear by reading it out....But doing the trendy language in the mission statement or the vision, it just turns people off because they go, "Well what does that mean?"

The trendy language is reference made to the trend among charities to adopt the management speak from the corporate world where statements are formulated in a similar ways using similar buzzwords The CEO also recognised this fact and believed that the mission needed to be crystallised in a more powerful way while being really clear about what the charity brand's unique niche on the healthcare charity market. Along with the vision and mission, top management also acknowledged the need to re-think the corporate brand values of the charity which seemed to have not been adequately promoted internally:

We're just working on our core values at the moment and we've got quite a long journey to go on developing our core values. I was shocked that I couldn't find any when I joined the charity. I think there were some buried in a document some time ago but there aren't any that live and breathe...So we've had a good discussion on the senior management team about the values and we had a discussion with the board about values last week.

Therefore, there seemed to be a consensus at the top level of management about the need to rethinking the brand foundation pillars such as the mission, vision and values. The lack of corporate brand clarity was also a major issue identified from the volunteers' perspectives as illustrated from the following excerpt from one of the branch chairs interviewed: 
So here I get it is the blind leading the blind. They are just not seeing. They got their eyes shut. They are not listening. Their heads are in the clouds. [...] It is how I feel. I don't want to get involved in these politics. I don't understand. You don't seem to relate to what I'm doing, and I don't understand what I'm doing. That is so upsetting.

Such perspectives from volunteers seem to confirm the need for more clarity in the articulation, implementation and communication of corporate brand foundations (vision, mission, values).

\section{Internal relational communications}

Data gathered from both volunteers and managers seemed to indicate a conflicting situation between senior management and many branches at grassroots level. This situation seemed to have been deteriorating over several years due to a lack of coherent internal communications approach stemming from the corporate brand values and personality. In fact, several volunteers interviewed felt that the feel and tone of management communication was very different to the image of warmth and care that the charity was projection to external audiences. When discussing this issue with senior management, a couple of them acknowledged this issue relating to tone of communication sent to branches in the past. The following excerpts from the head of fundraising illustrate this point:

[...] some of the communications that we've sent to them are awful. I've been embarrassed about some of the stuff that's been written. It seems very unfriendly and very standoffish and - I don't know. I think there needs to be a lot of bridge building between the two.

The national director also deplored the lack of efforts made on both sides to improve the situation but also mentioned the constraints and challenges involved:

It's at times a difficult relationship because what you don't have is, I think, as regular and as fertile a dialogue across the organisation as you would wish. And it's always easier to say than it is to do because in order for dialogue to happen and to be creative, there's got to be a willingness to engage at both ends, and there isn't always. I think both sides can stand some criticism and I think the simple truth is, it requires time, energy and human resource to make it happen.

From the perspective of volunteers, this issue is accentuated by the fact that, in many cases, they do not have any idea of the person behind the communications being sent to them.

I couldn't even say who they were. They are not making themselves as individuals known in an acceptable way to branch committees is my view. They 
are being driven and don't realize about the miscommunication - sending out letters that are bureaucratic, not the warmth that most of us experience [...]

It appeared that the charity did not have a consistent approach to internal communications over the past years. It was up to the individual manager to decide how they would wish to communicate with volunteers at branch level. It was also observed that some branches seemed to have been so affected by past communications (or lack of communications) from senior management that they do not even wish to interact with anyone that represents the corporate brand as illustrated in the following excerpt from one of the charity trustees interviewed:

I've been told by a couple of the branches: we don't want you there. We don't want one of them with us. They look upon UK office as them with a big salt that they can bring down at any time. They won't open up to even let me in. I have said to them, I want to meet your members. I am one of them. I said, I am one of the grassroots. I said, just because I am a trustee, I am any different than Joe Blocks down the road. Oh no, we don't want you!

In the case of this particular charity, it appears that some branches seem to be favouring a disengagement with the corporate brand due to the negative perceptions that have been developed over the years and amplified through inappropriate internal communications from management as well as informal communications among branch members as explained the national director as follows:

it's very difficult to shift that perception, particularly when they all talk to each other and say, "Do you know what's happened to us? We've had all our money taken away." That's dreadful. Have you heard about such and such? "It goes around and around and around and basically, like all good rumours, it gathers space and substance. And I'm not saying for one second that the UK office hasn't made a ball of it occasionally. I think it has, in terms of managing a relationship, it's actually been very left footed, occasionally.

\section{Internal brand presence}

While some branches have outwardly expressed the wish of not having any forms of contact with the corporate brand representatives, there are also those which would like to experience more corporate brand presence at grassroots level. These were branches that were either newly established or did not have a history of conflicting relationship with the head-office. Some of the representatives from these branches interviewed deplored the lack of face-to-face communication with corporate brand representatives as well as opportunities to engage with staff at senior 
management level. This sentiment is captured through the following views from one of the branch chairs interviewed:

It's just too much and you've got a branch that's been going for twelve months that's not seen not a hair of anybody for twelve months. And the people that run it, it's no wonder they get demoralised and say, "Well, if we've not got support, what's the point in carrying on?

Another chair of a branch located in London also expressed the wish for more faceto-face interaction opportunities to also allow for positive feedback opportunities:

I have never even told them you are brilliant at doing your publications, you are brilliant at your online stuff. I don't tell them because I don't meet them. I don't know them anymore. So, they are not getting the feedback.

There was also mention of branch executives to have opportunities to share and discuss their views with corporate brand management as expressed by another branch chair interviewed who recently set up a branch a year ago in the northern part of England:

I would like to sit down on an open forum and air my views with people that can give it consideration and possibly put it together and make it work. If it doesn't work, at least discuss it. But there's no chance of an open forum.

The lack of brand visibility in certain branches was also manifested through the absence of any form of corporate visual brand identifier during meetings. For instance, in several meetings that the researcher attended, there were no banners, posters or even small merchandise items that could give an indication to an outsider that this was a reunion of people form part of that particular charity. Moreover, the researcher also observed that some branches were producing external facing promotional materials such as leaflets without any support or guidance from the headquarters so that they could adhere to certain brand visual identity guidelines.

Senior management seemed to acknowledge that more could be done in terms of brand presence but they are faced with time and resource constraints as well as a history of hostility with some branches preventing them from taking a step in that direction as explained in the following excerpt from the head of fundraising:

I don't have any relationship with them, which is disappointing. I should have a better relationship with them. It's been a very tough eight months. When I first got here, I was thinking l'd go out and visit a few branches. I think one of the comments to me was, "Good luck with that." I've never really gone out there and met with the branches. I didn't want to go and jump into this frying pan of conflict [...] I have a list of things I need to do as head of fundraising. I've got a list of 
things as long as your arm and to try and prioritise the list of things I need to do in terms of the reduced amount of staff I have, my time is so restricted. Not that that is an excuse. I should do more...

\section{Discussion}

The aim of this study was to investigate and explore the issues and challenges faced by the charity through a corporate branding lens from the perspectives of both senior management and grassroot volunteers. Findings from this study suggest several important implications for both academic research and managerial practice. The main issues identified were around corporate brand clarity, internal relational communications and brand presence.

The importance of having a clear vision and mission for successful charity brand orientation has already been suggested in previous studies (e.g. Chapleo, 2015) but this study provides a more in-depth perspective of the tensions that can arise between management and volunteers resulting from a lack of brand clarity. The concept of brand clarity was defined in a consumer marketing context by Erdem \& Swait (2001) as: "the absence of ambiguity in the information conveyed by the brand's past and present marketing mix strategies and associated activities" (p. 137). In the context of managing and communicating the functional components of the corporate branding within a charitable organisation, this concept would relate to an absence of ambiguity in the articulation of the brand mission, vision and values and a more careful attention to how these are aligned with the realities of volunteers at grassroots level. Our findings also suggest that brand orientation in a charity context might not work as fluidly as suggested in previous studies where a top-down managerial driven approach is suggested to promote and distil brand values among internal audiences (e.g. Chapleo, 2015; Liu et al., 2015). Our findings suggest that, depending on the specificities of the charity, internal brand orientation might work better through a circular approach where volunteers at grassroots level (e.g. branches) are included at the beginning of any initiative that is meant "to create a favorable organizational environment for the process of internal branding to take place" (p. 334).

Another key finding from this study seemed to be related to the crucial role of relational communications which has been defined in the social psychology literature as the "affective or expressive dimension of group communications" (Keyton 1999, p. 
192) that can contribute in creating and maintain a social fabric meant to promote positive relationships among different groups with the organisation (Keyton, 1999). Previous studies have identified internal communications as a key success factor for successful charity brand orientation from a senior managers' perspective (e.g. Chapleo, 2015; Liu, 2015) but this study reveals in more depth the complexities of internal communications including both formal and informal manifestations (Kalla, 2005; Welch and Jackson, 2007). In this particular context, it was observed that senior management has been accumulating a considerable amount of negative perception over the years due to a lack of consistent internal communications strategy where senior management seemed to have limit themselves to functional communications with branches (e.g. circular letters) while neglecting the relational aspect of communications that is meant to build and maintain positive relationships with internal audiences. This study suggests that in that charity context, relational managerial communication meant to build and nurture relationships with volunteers can be as important, if not more important, as functional communications. Therefore, for charities to communicate effectively and for brand orientation to work effectively, there needs to be an integrated internal communications strategy that involves the full participation of volunteers. For instance, given the size of the charity and the operational constraints on senior managers, a selected group of volunteers could be trained and entrusted with the responsibility with managing some of the internal communication channels. The idea here is to think of internal communications in a more strategic way rather than relying on the specific skills of certain employees (Kalla, 2005). The charity CEO also needs to lead by example in that process with more frequent communications that projects internally the brand personality and values promoted to external stakeholders. This study revealed that some volunteers did not perceive the CEO an effective communicator and this influenced how they perceived their relationship with the corporate brand. In a study on CEO communication style, Men (2015) found that CEO communication who demonstrated certain empathetic characteristics (e.g. warmth, friendliness, compassion, etc.) where more likely to be perceived by audiences as effective communicators. Therefore, in a charity context, CEOs should not only focus on the task dimension of their roles (e.g. assertive circular letters) but also need to show a compassionate and listening side (Men 2015) hence favouring a more relationship-oriented style of leadership (Mikkelson et al., 2019). 
The volunteers interviewed also deplored the lack of face-to-face interaction with senior management as one of the causes of such relational communications conflict. This situation seemed to concur with findings from precious studies in organisational internal communications (e.g. Tourish and Hargie, 1996) who posited that organisations needed to find "as many creative ways as possible of enabling more face-to-face interaction to take place between managers and other organizational members" (p. 15). However, in large organisations such as national charities, it has also been observed that "it would be unrealistic to suggest that internal corporate communication can be conducted principally as face-to-face dialogue" (Welch and Jackson 2007, p. 187). Therefore, large charities with operational constraints might find it useful to explore "a diverse spectrum of traditional face-to-face strategies in addition to social, mobile, and digital tactics to best facilitate continuous, accessible, and respectful dialogue with all publics" (Place 2019, p. 13). Some recent studies have also suggested that managers need to engage more with new technologies that can allow more opportunities for social interaction (Palomares et al., 2017). For instance, Oltarzhevskyi (2019) proposed a few innovative avenues that could support face-toface communications and a closer connection with internal audiences such as the use of an internal mobile portal that could provide corporate news and other relevant information on a $24 / 7$ basis (p. 619). While it can be argued that some audiences might not have access or might not be comfortable with such technologies (Place 2019), we should also not underestimate the capacity for audiences to adapt to and engage with new forms of mediated communication.

Another issue identified in this study was the insufficient visibility of the corporate brand at grassroots levels from the perspective of some volunteers. This is an issue that has already been identified in previous research within commercial contexts where Tourish (1997) identified that one of the most come complaints that people made about senior management was their lack of visibility. Tourish (1997) suggested that in order to heighten their "visibility factor" (p. 115), senior managers could start with small steps (e.g. drink coffee in staff canteen) and think of bolder tactics with experience. In a national charity context where the headquarters are physically distant from grassroots branches, there is an added level of complexity for senior managers. There need to therefore think more creatively in how mediated technologies could allow them to enhance their visibility factor in branches which 
would also contribute to ensure a stronger corporate brand presence in those spaces. Communication tactics such as recorded video messages or podcasts could be considered as well as live interventions during branch meeting using mobile applications such as WhatsApp or Zoom. Moreover, volunteers with more time on their plate could be trained as 'brand champions' to reinforce the corporate expression of the brand at regional level. In their study of global non-profits, Laidler-Kylander and Simonin (2009) suggested that such organisations needed to encourage internal brand ambassadors to promote "an understanding of the brand, internally communicating the importance of the brand, and ensuring that the internal and external perceptions of the brand are in alignment" (p.67).

\section{Conclusions}

The aim of this study was to investigate issues and challenges faced by a charity brand internally from the perspectives of both senior management and grassroots volunteers. Research on internal branding within a non-profit or charity context is still nascent and the few studies that have explored issues around internal branding in this specific sector have mostly favoured the managerial perspective. This study provided a unique perspective within a specific charity context hence contributing empirically to the growing number of case studies exploring specific issues and challenges faced by charities in the management of their corporate brands. This study lays emphasis on the importance of internal brand clarity, relational communications and internal brand presence in the successful management of the corporate brand internally.

Our study seems to indicate that charities needed to ensure internal brand clarity at different levels of the organisation and ensure the main pillars of the corporate brand (vision, mission, values) are elements that volunteers at grassroots level can experience and put into action easily in their day-to-day dealings with members and other beneficiaries of the charity. Internal communications were found to be a crucial element in internal corporate branding initiatives and findings from this study suggest that relational communications should be given more weight in communicating with internal stakeholders. This study also found that internal brand presence which refers 
to the physical or experiential manifestation of the corporate brand at different levels of the organisation was also a key determinant for successful internal brand orientation within a charity context especially with the existence of numerous independently-run branches operating under the charity brand. Several managerial actions have been proposed in light of the findings illustrated by several tactical recommendations.

This study focused on the specific case of a national healthcare charity operating in the UK with a limited sample of participants which could limit the generalisation of findings. However, the rich insights gathered within such a specific context is likely to contribute empirically to the body of research on charity branding which already include numerous case studies from diverse settings. Future research could further test in a more robust manner and using a larger sample base the main constructs identify as salient in this current study. The role of internal communications, especially relational communications, in the effective management of the corporate brand internally needs to be investigated further and possibly drawing from group communication theories already established within social psychology and sociology. Another stream of future investigation could also be around the dark side of internal corporate brand management within the charity context as well as dysfunctional internal communications systems that could adversely be impacting on the corporate brand externally.

\section{References}

Balmer, J. (1995), "Corporate branding and connoisseurship”, Journal of General Management, Vol. 21 No. 1, pp.22-46

Balmer J. (1998), "Corporate identity and the advent of corporate marketing", Journal of Marketing Management, Vol 14 No. 8, pp.963-996.

Balmer J. (2001), "Corporate identity, corporate branding and corporate marketing seeing through the fog", European Journal of Marketing, No. 35, pp.248-291.

Balmer J. (2006), "Corporate brand cultures and communities", Schroeder, J, and Salzer-Morling, M. (Ed.), Brand Culture, New York, NY, pp.30-43.

Balmer, J.M.T. and Gray, E. (2003), "Corporate brands: what are they? What of them?”, European journal of marketing, Vol. 37, pp.972- 997. 
Bennett R. and Gabriel H. (2003), "Image and reputational characteristics of UK charitable organisations: An Empirical Study", Corporate Reputation Review, Vol.6 No.3, pp.276-289.

Braun V. and Clarke V. (2006), "Using thematic analysis in psychology", Qualitative Research in Psychology, Vol.3, pp.77-101.

Charity Commission (2020), "Register of Charities", available at: http://apps.charitycommission.gov.uk/showcharity/registerofcharities/SectorData/Sec torOverview.aspx) (Accessed 19 January 2020).

Chapleo, C. (2015), "Brand 'infrastructure 'in nonprofit organizations: Challenges to successful brand building?", Journal of Marketing Communications, Vol. 21, No. 3, pp.199-209.

Creswell, J. W., (1998), Qualitative Inquiry and Research Design: Choosing Among Five Traditions, London.

De Chernatony, L. (2002), "Would a brand smell any sweeter by a corporate name?", Corporate Reputation Review, Vol. 5, No. 2-3, pp.114-132.

Denzin, N. K. and Lincoln, Y. S. (2003), "Introduction: The discipline and practice of qualitative research", Denzin N. K. and Lincoln, Y. S. (Eds.), Strategies of Qualitative Inquiry, Sage Publications, CA, pp.1-45.

Erdem, T. and Swait, J. (2001), "Brand equity as a signaling", Journal of consumer Psychology, Vol. 7 No. 2, pp.131-157.

Foster, E. and Bochner, A. P. (2008), "Social constructionist perspectives in communication research", Holstein, J. A. and Gubrium, J. F. (Eds). Handbook of Constructionist Research, The Guildford Press, NY, pp.85-106.

Garg, E., Swami, S., and Malhotra, S. K. (2019), "Branding effectiveness measurement in nonprofit environment", Journal of Advances in Management Research, Vol. 15, No.1, pp.4-22.

Gioia, D. A., Corley, K. G., and Hamilton, A. L., (2013), "Seeking qualitative rigor in inductive research notes on the Gioia methodology", Organizational Research Methods, Vol.16 No.1, pp.15-31.

Griffiths, M. (2005), "Building and rebuilding charity brands: the role of creative agencies", International Journal of Nonprofit and Voluntary Sector Marketing, No.10, pp.121-132.

Grounds, J. and Harkness, J. (1998), "Developing a brand from within: Involving employees and volunteers when developing a new brand position", International Journal of non-profit and voluntary sector marketing, Vol.3, pp.179-184. 
Gyrd-Jones, R., Merrilees, B., and Miller, D. (2013), "Revisiting the complexities of corporate branding: Issues, paradoxes, solutions", Journal of Brand Management, Vol. 20 No. 7, pp.571-589.

Hankinson, P. (2000), "Brand orientation in charity organisations: qualitative research into key charity sectors", International Journal of non-profit and voluntary sector marketing, Vol. 5, No.3, pp.207-219.

Hankinson P. (2001a), "Brand orientation in the charity sector: A framework for discussion and research", International Journal of Nonprofit and Voluntary Sector Marketing, No.6, pp.231-242.

Hankinson, P. (2001b), "Brand orientation in the top 500 fundraising charities in the UK", Journal of Product and Brand Management, No.10, pp.346-360.

Hankinson, P. (2004), "The internal brand in leading UK charities", Journal of Product and Brand Management, Vol.13, No.2, pp.84-93.

Ind, N. and Bell M. (1999), "Freedom and order: a participative approach to corporate branding", Journal of Brand Management, Vol. 7, No.1, pp.19-26.

Kalla, H.K. (2005). "Integrated internal communications: a multidisciplinary perspective", Corporate Communications: An International Journal, Vol.10 No.4, pp.302-314.

Kapferer, J. N. (2002), "Corporate brand and organizational identity”, Moingeon, B. and Soenen, G. (Eds.), Corporate and Organizational identities: Integrating Strategy, Marketing, Communication and Organizational perspectives, Routledge, NY, pp.175194.

Keyton, J. (1999), "Relational communication in groups", Frey, L. (Ed.), The Handbook of Group Communication Theory and Research, Sage Publications, CA, pp.192-222.

King, S. (1991), "Brand building in the 1990s", Journal of Consumer Marketing, Vol. 8, No. 4, pp.43-52.

Kitchen, P., Tourky, M., Dean D. and Shaalan, A. (2013), "Corporate identity antecedents and components: Toward a theoretical framework", Corporate Reputation Review, Vol. 16 No. 4, pp.263-284.

Knox, S. and Bickerton, D. (2003), "The six conventions of corporate branding", European Journal of Marketing, Vol. 37, No.7/8, pp.998-1016.

Laidler-Kylander, N. and Simonin, B. (2009), "How international non-profits build brand equity", International Journal of non-profit and voluntary sector marketing, Vol.14 No.1, pp. 57-69.

Laidler-Kylander, N. and Stenzel, J.S. (2013), "The brand IDEA: Managing Nonprofit Brands with Integrity, Democracy, and Affinity", Jossey-Bass, California, CA. 
Leitch, S. and Motion, J. (2007), "Retooling the corporate brand: A Foucauldian perspective on normalisation and differentiation", Journal of Brand Management, Vol. 15 No.1, pp.71-80.

Liu, G., Chapleo, C., Ko, W.W. and Ngugi, I.K. (2015), "The role of internal branding in nonprofit brand management: An empirical investigation", Nonprofit and Voluntary Sector Quarterly, Vol. 44 No. 2, pp.319-339.

Macrae, C. (1999), "Brand reality editorial", Journal of Marketing Management, Vol.15, pp.1-24.

Men, L.R. (2015), "The internal communication role of the chief executive officer: Communication channels, style, and effectiveness", Public Relations Review, Vol. 41 No.4, pp.461-471.

Mikkelson, A.C., Sloan, D. and Hesse, C. (2019), "Relational communication messages and leadership styles in supervisor/employee relationships", International Journal of Business Communication, Vol.56 no.4, pp.586-604.

Olins, W. (2003), Wally Olins on Brand, Thames and Hudson, London.

Oltarzhevskyi, D.O. (2019), "Typology of contemporary corporate communication channels", Corporate Communications: An International Journal, Vol.24 No.4, pp.608-622.

Palomares, M.I., Navarro, C. and Lara, J.Á.S., (2018), "Determining factors of success in internal communication management in Spanish companies", Corporate Communications: An International Journal, Vol. 23 no.3, pp.405-422.

Place, K.R., (2019), "Exploring digital, social and mobile dialogic engagement with low-income publics", Public Relations Journal, Vol.12, No.4, pp. 1-17.

Pope, J. A., Isely, E. S., and Asamoa-Tutu, F. (2009), "Developing a marketing strategy for nonprofit organizations: An exploratory study", Journal of Nonprofit and Public Sector Marketing, Vol. 21, No.2, pp.184-201.

Punjaisri, K. and Wilson, A., (2017), "The role of internal branding in the delivery of employee brand promise”, Balmer J.M.T., Powell S.M., Kernstock J., and Brexendorf T.O. (Eds.), Advances in Corporate Branding, Palgrave Macmillan, London, pp. 91-108.

Roberts-Wray, B., (1994) "Branding, product development and positioning the charity”, Journal of brand management, Vol.1 No.6, pp.363-70.

Roper S. and Davies G. (2007), "The corporate brand: dealing with multiple stakeholders”, Journal of Marketing Management, Vol. 23, No.1-2, pp.75-90.

Saxton, J., (1994), "A strong charity brand comes from strong beliefs and values", Journal of Brand Management, Vol. 2, No.4, pp.211-220. 
Schultz, M., and De Chernatony, L., (2002), "The challenges of corporate branding", Corporate Reputation Review, Vol. 5, No. 2/3, pp.105-113.

Schmeltz, L. and Kjeldsen, A.K., (2019), "Co-creating polyphony or cacophony? A case study of a public organization's brand co-creation process and the challenge of orchestrating multiple internal voices", Journal of Brand Management, Vol. 26, No.3, pp.304-316.

Stride H. (2006), "An investigation into the values dimensions of branding: Implications for the charity sector", International Journal of Nonprofit and Voluntary Sector Marketing, No. 11, pp.115-124.

Stride, H. and Lee, S. (2007), "No logo? No way. Branding in the nonprofit sector", Journal of Marketing Management, Vol. 23, No. 1-2, pp.107-122.

Schultz, M., Hatch, M.J. and Adams, N., (2012), "Managing corporate reputation through corporate branding", Barnett, M. and Pollock, T. (Eds.), The Oxford Handbook of Corporate Reputation, Oxford University Press, Oxford, pp.420-446.

Suomi, K., Saraniemi, S., Vähätalo, M., Kallio, T. J., and Tevameri, T. (2019), "Employee engagement and internal branding: Two sides of the same coin?", Corporate Reputation Review, pp.1-16.

Tapp, A. (1996), "The use of brand management tools in charity fundraising", Journal of Brand Management, Vol. 3, No. 6, pp.400-410.

Tourish, D. and Hargie, C. (1996), "Internal communication: key steps in evaluating and improving performance", Corporate Communications: An International Journal, Vol. 1 No. 3, pp.11-16.

Tourish, D. (1997), "Transforming internal corporate communications: the power of symbolic gestures and barriers to change", Corporate Communications: An International Journal, Vol.2 No.3, pp.109-116.

Van Riel C. and Balmer J. (1997), "Corporate identity: The concept, its measurement and management", European Journal of Marketing, Vol. 31 No.5/6, pp. 340-355.

Welch, M. and Jackson, P.R. (2007), "Rethinking internal communication: a stakeholder approach", Corporate communications: An international journal, 12(2), pp.177-198.

Wymer, W. and Akbar, M. (2018), "Brand authenticity's influence on charity support intentions", Journal of Nonprofit and Public Sector Marketing, Vol. 31 No. 5, pp.507527. 